\title{
Tepung ulat sagu (Rhyinchophorus ferrugineus) imunomodulator Nitric Oxide (NO) sirkulasi mencit terapi antimalaria standar
}

\author{
Ariani $^{1}$, Gemala Anjani ${ }^{1}$, Muchlis Achasan Sufro Adji ${ }^{2}$, Kis Djamiatun ${ }^{3 *}$
}

\begin{abstract}
Background : Sago worm flour (Rhyinchophorus ferrugineus)is a coconut beetle larvae that is processed into flour.This flour contains antioxidants as well as arginine, both of which play a role in modulating oxidative stress including NO involved in immunopathology of cerebral malaria.

Objectives : To prove the immunomodulator role of sago worm flour in decreasing circulation NO level at mice who received standard antimalarial therapy Dihydroartemisinin Piperaquine (DHP)

Methods : This study was randomized control group post test only design by using 23 Swiss mice which divided into 5 group consist of : $K(-)$ normal mice; $K(+)$ inoculated woth Plasmodium berghei ANKA (PbA); X1 received DHP; X2 received sago worm flour; X3 received both of sago worm flour and DHP. All treatment groups X1,X2 and X3 were inoculated by PbA before treatmen were given. Serum circulation NO level was assessed by ELISA. statistical analysis used was One Way ANOVA followed by Bonferroni post hoc test.

Results : The mean NO level in $K(-), K(+), X 1, X 2$, and $X 3$ were $1.008 \mu \mathrm{mol} / \mathrm{mL}, K(+) 1.338 \mu \mathrm{mol} / \mathrm{mL}$; while at treatment X1 $1.143 \mu \mathrm{mol} / \mathrm{mL}, X 21.410 \mu \mathrm{mol} / \mathrm{mL}$, dan X3 $0.886 \mu \mathrm{mol} / \mathrm{mL}$. One way ANOVA showed that they were significantly different $(p=0.001)$. Bonferroni post hoc test of X2 was proportional to $K(+)(p=1.000)$, whole had NO level lower than either $K(+)(p=0.009)$ or $X 2(p=0.002)$.

Conclusion : The immunomodulatory effects of sago worm flour (Rhyinchophorus ferrugineus) reduced circulating NO levels in standard antimalarial therapy recipients.
\end{abstract}

Keywords : Sago worm, Plasmodium berghei ANKA (PbA), NO

\section{ABSTRAK}

Latar Belakang : Tepung ulat sagu (Rhyinchophorus ferrugineus) merupakan larva kumbang merah kelapa yang diolah hingga menjadi tepung.Tepung ini mengandung antioksidan sekaligus arginin, keduanya berperan memodulasi stres oksidatif termasuk NO yang terlibat pada imunopatologi malaria serebral.

Tujuan : Membuktikan peran imunomodulator tepung ulat sagu (Rhyinchophorus ferrugineus) menurunkan kadar NO sirkulasi pada mencit yang mendapat terapi antimalaria standar Dhydroartemisinin Piperaquine (DHP).

Metode : Penelitian ini merupakan penelitian eksperimental dengan desain post test only randomized control group dengan menggunakan mencit Swiss sebanyak 23 ekor yang terbagi dalam 5 kelompok perlakuan yaitu K(-) mencit sehat, K(+) mencit yang diinokulasi_Plasmodium berghei ANKA (PbA), kelompok perlakuan X1 diberi DHP, X2 diberi tepung ulat sagu, dan X3 diberi tepung ulat sagu dan DHP. Semua kelompok perlakuan X1,X2, dan X3 diinokulasi PbA sebelum diberikan perlakuan. Kadar NO sirkulasi diperiksa dari serum darah mencit dengan metode ELISA. Uji statistik yang digunakan adalah One way ANOVA dilanjutkan uji post hoc Bonferroni.

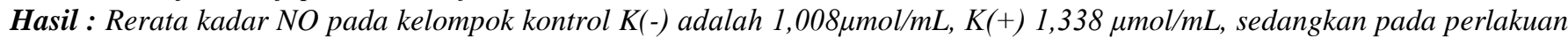

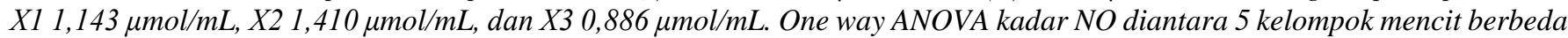
bermakna $(p=0,001)$. Uji Bonferroni menunjukkan kadar NO X2 sebanding dengan $K(+)(p=1,000)$, sementara kelompok X3 lebih rendah dari $K(+)(p=0,009)$ maupun $X 2(p=0,002)$.

Simpulan : Efek imunomodulator tepung ulat sagu (Rhyinchophorus ferrugineus) mampu menurunkan kadar NO sirkulasi pada mencit terapi antimalaria standar.

Kata Kunci : Ulat sagu, Plasmodium berghei ANKA, NO

\section{PENDAHULUAN}

\footnotetext{
1. Departemen Ilmu Gizi, Fakultas Kedokteran, Universitas Diponegoro. Jl. Prof. Sudarto SH, Tembalang, Semarang, Jawa Tengah 50275

2. Ilmu Penyakit Dalam, RS. Kariadi Semarang, Fakultas Kedokteran, Universitas Diponegoro. Jl. Doktor Sutomo, Randusari, Semarang 50244

3. Parasitologi, Fakultas Kedokteran, Universitas Diponegoro. Jl. Prof. Sudarto SH, Tembalang, Semarang, Jawa Tengah 50275

*Korespondensi : e-mail: kisdjamiatun@gmail.com
}

Malaria sampai saat ini masih menjadi salah satu masalah kesehatan masyarakat terutama di daerah tropis. Hampir setengah dari populasi dunia Tahun 2015 berisiko terkena malaria. Sejumlah 214 juta kasus malaria baru di seluruh dunia dengan jumlah kasus terbesar di wilayah Afrika 88\%. ${ }^{1}$ Prevalensi malaria Tahun 2015 berdasarkan Annual Parasite Incidence (API) sebanyak 0,85 per 1.000 penduduk Indonesia dengan jumlah kasus 209.413, dan kasus terbanyak berada di Provinsi Papua. ${ }^{2}$ Tingginya angka kesakitan dan kematian pada penderita malaria diakibatkan oleh 
resistensi obat antimalaria yang sering digunakan terhadap plasmodium. Akibat adanya resistensi obat antimalaria yaitu klorokuin dan SulfadoksinPirimethamin (SP) untuk mengobati pasien malaria di Papua, maka penanggulangan resistensi yang direkomendasikaan World Health Organization (WHO) saat ini menggunakan kombinasi derivate artemisinin dengan obat antimalaria lainnya yang disebut dengan Artemisinin based Combination Therapy (ACT). ${ }^{3}$ Turunan artemisinin pada obat oral antimalaria yang digunakan di Indonesia antara lain kombinasi DHP dalam bentuk fixed dose tablet $40 \mathrm{mg}$ dihydroartemisinin dan $320 \mathrm{mg}$ piperaquine phosphate. Dosis dihydroartemisinin 2-4 $\mathrm{mg} / \mathrm{kgBB}$ dan piperaquine $16-32 \mathrm{mg} / \mathrm{kgBB} /$ dosis tunggal, diberikan selama 3 hari. ${ }^{1,4}$

Malaria sebagai penyakit infeksi parasit yang disebabkan Plasmodium, menginfeksi eritrosit (sel darah merah) dan mengalami pembiakan aseksual di jaringan hati dan eritrosit. ${ }^{5}$ Eritrosit yang terinfeksi Plasmodium menyebabkan aktivasi makrofag yang selanjutnya mensekresikan NO, dan mengaktifkan sel natural killer (NK) yang selanjutnya mensekresi Interferon gamma(IFN $\gamma){ }^{6} \quad$ Infeksi $\quad$ Plasmodium merangsang respon imun pejamu untuk melawan parasit tersebut, dengan melibatkan makrofag, limfosit$\mathrm{T}$, dan sel-sel imun lainnya, juga pembentukan reactive oxygen species (ROS) yang bersifat oksidatif untuk membunuh Plasmodium. Stres oksidatif yang terjadi pada infeksi Plasmodium dapat menurunkan respon imun, dan menurunkan konsentrasi antioksidan yang terjadi seiring dengan pematangan parasit. $^{7} \mathrm{NO}$ berhubungan dengan kejadian malaria berat, dan berperan sebagai mediator respon imun yang melindungi pejamu dari stadium eritrosit Plasmodium, pada malaria. ${ }^{6,8}$ Selama infeksi malaria, peningkatan mediator pro-inflamasi dan produksi NO telah dikaitkan dengan patogenesis dan keparahan penyakit. Studi in vivo dan in vitro baik hemozoin Plasmodium falciparum dan glycosylphosphatidylinositols mampu memodulasi sel mononuklear darah, berkontribusi menstimulasi transduksi sinyal dan regulasi jalur pensinyalan NF-кB. ${ }^{9}$ Infeksi yang berlebihan menyebabkan kenaikan jumlah NO yang lebih banyak. Jumlah NO yang berlebihan akibat infeksi akan diubah menjadi peroksinitrit $\left(\mathrm{ONOO}^{-}\right)$yang merupakan radikal bebas sehingga sel mengalami stres oksidatif. ${ }^{10}$ Keanekaragaman hayati cukup tinggi di Indonesia, akan tetapi belum dimanfaatkan secara optimal untuk memenuhi kebutuhan hidup. Salah satu keanekaragaman hayati berupa hutan sagu. Penyebaran sagu cukup luas di Indonesia Timur, masyarakat Maluku dan Papua menjadikan sagu sebagai makanan pokok dan memanfaatkan ulat sagu, serta percaya bahwa mengonsumsi ulat sagu memiliki efek menguntungkan bagi kesehatan. ${ }^{11}$ Ulat sagu berasal dari larva kumbang merah kelapa yang diperoleh dari pembusukan pohon sagu setelah sebagian besar dagingnya diolah menjadi tepung sagu. ${ }^{12}$ Penelitian lain menunjukan bahwa penggunaan ACT mempengaruhi berbagai petanda malaria antara lain menghambat metabolisme parasit, menurunkan indeks parasit serta meghambat sintesis dari NO.${ }^{13}$ Kandungan metionin yang merupakan antioksidan dalam tepung ulat sagu dapat menekan radikal bebas termasuk NO pada mencit Swissyang diinokulasi Plasmodium berghei ANKA $(\mathrm{PbA})$. Berdasarkan latar belakang tersebut, serta terbatasnya penelitian dosis tepung ulat sagu maka penelitian ini dilakukan pada model binatang coba yaitu mencit, serta dilakukan penelitian efek imunomodulator tepung ulat sagu dalam menurunkan kadar NO sirkulasi pada mencit terapi antimalaria standar. Penelitian ini menggunakan mencit Swiss berusia 8-10 minggu dengan berat 25-35 g. Penggunaan mencit tersebut cukup sensitif terhadap infeksi parasit serta memiliki survival time lebih panjang terhadap infeksi $\mathrm{PbA}$.

\section{BAHAN DAN METODE}

Penelitian ini merupakan penelitian eksperimental dengan desain post test only randomized control group. Penelitian ini dilakukan di Laboratorium Parasitologi, Fakultas Kedokteran Universitas Gadjah Mada selama 22 hari pada bulan November - Desember 2017. Penelitian ini telah mendapatkan persetujuan Etik Penelitian Kesehatan Fakultas Kedokteran Universitas Diponegoro-RSUP. Dr. Kariadi Semarang dengan Sertifikat No.05/EC/H/FK-RSDK/I/2018.

Sampel pada penelitian adalah mencit Swiss, dari laboratorium penelitian dan pengujian terpadu (LPPT) Universitas Gadjah Mada dan memenuhi kriteria inklusi yang berjenis kelamin betina, mencit_dalam keadaan sehat yang ditandai dengan nafsu makan baik dan bergerak aktif, anatomis normal, umur 8-10 minggu, dan berat badan 25-35 g. Kriteria mencit eksklusi apabila mencit mati selama penelitian, dan sampel darah lisis. Bahan penelitian yang digunakan adalah ulat sagu yang diperoleh dari Kampung Taroy Kabupaten Teluk Bintuni Papua, reagen Griess untuk uji kadar NO. Alat yang digunakan dalam penelitian ini berupa oven, blender, ayakan tepung, kandang mencit, tempat makanan dan minum, sonde, timbangan, mikropipet, microtube, sentrifuge, dan ELISA microplate reader.

Pembuatan tepung ulat sagu dengan cara ulat sagu dicuci bersih dan dikeringkan menggunakan oven dengan suhu $100^{\circ} \mathrm{C}$ selama 5 jam. Ulat sagu kering digiling hingga menjadi tepung. Tepung ulat sagu kemudian dilakukan pemeriksaan kandungan protein dengan metode Kjeldahl, pemeriksaan kadar air, 
lemak, serat, karbohidrat dan abu berdasarkan metode SNI 012891 1992, antioksidan tepung ulat sagu berdasarkan metode DPPH. Pemeriksaan asam amino tepung ulat sagu dengan metode HPLC. PbA didapat dari Laboratorium Parasitologi Fakultas Kedoketan Universitas Gadjah Mada. Dosis inokulasi PbA adalah $10^{7}$ eritrosit berparasit dalam $0,1 \mathrm{ml}$ suspensi diinokulasikan secara intra peritoneal menggunakan spuit $1 \mathrm{cc}$.

Setelah menjalani masa adaptasi selama 7 hari, 23 ekor mencit dibagi ke_dalam 5 kelompok, 2 kelompok kontrol dan 3 kelompok perlakuan. Kelompok kontrol $\mathrm{K}(-)$ mencit sehat yang hanya diberikan pakan satndar, Kelompok kontrol $\mathrm{K}(+)$ diberikan pakan standar dan diinokulasi $\mathrm{PbA}$, kelompok perlakuan 1 (X1) diberikan pakan standar, diinokulasi $\mathrm{PbA}$ dan terapi antimalaria Dihydroartemisinin $\quad 0,546 \mathrm{mg} / 20 \quad \mathrm{~g} \quad \mathrm{BB} / \mathrm{hari}$, piperaquine $0,006 \mathrm{mg} / 20 \mathrm{~g} \mathrm{BB} /$ hari, kelompok perlakuan 2 (X2) diberi tepung ulat sagu dosis 534 $\mathrm{mg} / 20 \mathrm{~g} \mathrm{BB}$ per oral selama 14 hari dan diinokulasi $\mathrm{PbA}$, kelompok perlakuan 3 (X3) diberi tepung ulat sagu dosis $534 \mathrm{mg} / 20 \mathrm{~g}$ BB per oral selama 14 hari dan diinokulasi $\mathrm{PbA}$, serta mendapat antimalaria Dihydroartemisinin $\quad 0,546 \mathrm{mg} / 20 \mathrm{~g} \quad \mathrm{BB} / \mathrm{hari}$, piperaquine $0,006 \mathrm{mg} / 20 \mathrm{~g} \mathrm{BB} /$ hari. Hari ke-15 sampel diinokulasi $\mathrm{PbA}$ yang berasal dari mencit donor yang di dapatkan dari Laboratorium Parasitologi Fakultas Kedokteran Universitas Gadjah Mada, dengan kandungan $10^{7} \mathrm{ml}$ eritrosit berparasit yang diinokulasikan sebanyak $0,1 \mathrm{ml}$ secara intra peritoneal menggunakan spuilt $1 \mathrm{cc}$. Pemberian antimalaria Dihydroartemisinin Piperaquine diberikan pada hari ke-3 setelah inokulasi selama 3 hari. Hari ke-22 pengambilan sampel darah pada mencit melalui jantung sebanyak $\pm 1 \mathrm{cc}$. Mencit dibius dengan narkose menggunakan kloroform. Darah dimasukan ke dalam microtube yang sebelumnya sudah diberi label sampel, dan didiamkan selama 1 jam kemudian di sentrifus 7.000 RPM selama 5 menit. Serum darah yang terpisah dimasukan ke microtube menggunakan pipet 0,2-200 $\mu 1$. Pemeriksaan kadar NO menggunakan serum darah dengan metode ELISA.

\section{HASIL}

Uji kandungan zat gizi sebagai uji pendahuluan, dilakukan di Laboratorium Terpadu Universitas Diponegoro dan Laboratorium Terpadu (Ilmu Nutrisi dan Pakan) POLTEKES Surabaya. Analisis yang dilakukan secara duplo. Hasil analisis kandungan zat gizi tepung ulat sagu (Rhynchophorus ferrugineus) disajikan pada Tabel 1. Hasil analisis tepung ulat sagu dengan metode DPPH menunjukan bahwa kandungan antioksidan sebesar 78,6 \% per 100 g.Hasil analisis kandungan asam amino tepung ulat sagu disajikan pada Tabel 2. Hasil analisis $100 \mathrm{~g}$ dalam uji pendahuluan penelitian kandungan zat gizi tepung ulat sagu menunjukan bahwa kandungan protein sebesar 33,68 $\%$ per $100 \mathrm{~g}$ dan kandungan antioksidan sebesar 78,6 $\%$ per $100 \mathrm{~g}$.

Tabel 1. Hasil Analisis Kandungan Zat Gizi Tepung Ulat Sagu

\begin{tabular}{lc}
\hline \multicolumn{1}{c}{ Parameter Uji } & Hasil (\%/100g) \\
\hline Protein & 33,68 \\
Kadar air & 1,00 \\
Lemak & 18,09 \\
Abu & 2,63 \\
Karbohidrat & 8,69 \\
Serat & 40,3 \\
Antioksidan & 78,6 \\
\hline
\end{tabular}

Tabel 2. Hasil Analisis Kandungan Asam Amino Tepung Ulat Sagu

\begin{tabular}{lc}
\hline \multicolumn{1}{c}{ Asam Amino (dry weight) } & Hasil $(\boldsymbol{\%} / \mathbf{1 0 0 g})$ \\
\hline Asamaspartate & 1,870 \\
Asamglutamat & 2,739 \\
Serin & 1,650 \\
Glisin & 8,024 \\
Histidin & 1,230 \\
Arginin & 1,001 \\
Prolin & 1,968 \\
Tirosin & 1,877 \\
Valin & 1,140 \\
Metionin & 1,091 \\
Isoleusin & 1,002 \\
Fenilalanin & 2,183 \\
Lisin & 1,988 \\
\hline
\end{tabular}

\section{Karakteristik Hasil Penimbangan Berat Badan Mencit}

Penimbangan berat badan mencit selama penelitian dilakukan sebanyak 4 kali, yaitu pada saat masa adaptasi, perlakuan, inokulasi dan terminasi. Analisis statistik dilakukan dengan uji One Way Anova untuk melihat perbedaan berat badan mencit dengan nilai signifikan $p<0,05$. Hasil analisis penimbangan berat badan mencit selama penelitian dapat dapat dilihat pada Tabel 3 .

Hasil penimbangan menunjukan bahwa berat badan (BB) pada saat adaptasi ada perbedaan $(p=0,036)$, walaupun demikian perbedaan tersebut tidak ditemukan pada akhir adaptasi dimana dimulai perlakuan $(p=0,086)$. Perbedaan BB juga tidak ditemukan saat dilakukan inokulasi $\mathrm{PbA}(p=0,236)$. Perbedaan bermakna BB teramati pada saat terminasi yaitu hari ke 7 pasca inokulasi $\mathrm{PbA}(p=0,009)$ (Tabel $3)$. 
Tabel 3. Hasil Analisis Berat Badan Mencit

\begin{tabular}{lccccc}
\hline \multirow{2}{*}{$\begin{array}{c}\text { Kelompok } \\
\text { Perlakuan }\end{array}$} & $\mathbf{n}$ & $\begin{array}{c}\text { Adaptasi } \\
\mathbf{x} \pm \text { SD }\end{array}$ & $\begin{array}{c}\text { Perlakuan } \\
\mathbf{x} \pm \text { SD }\end{array}$ & $\begin{array}{c}\text { Inokulasi } \\
\mathbf{x} \pm \text { SD }\end{array}$ & $\begin{array}{c}\text { Terminasi } \\
\mathbf{x} \pm \text { SD }\end{array}$ \\
\hline $\mathrm{K}(-)$ & 5 & $30,00 \pm 3,5$ & $31,40 \pm 3,2$ & $35,00 \pm 2,9$ & $36,00 \pm 2,1$ \\
$\mathrm{~K}(+)$ & 5 & $25,80 \pm 2,7$ & $27,40 \pm 2,5$ & $31,80 \pm 3,4$ & $30,60 \pm 3,1$ \\
$\mathrm{X} 1$ & 5 & $27,00 \pm 2,4$ & $30,20 \pm 2,5$ & $31,40 \pm 3,6$ & $30,00 \pm 3,6$ \\
$\mathrm{X} 2$ & 5 & $25,60 \pm 0,9$ & $28,40 \pm 1,5$ & $30,00 \pm 2,0$ & $28,20 \pm 2,2$ \\
$\mathrm{X} 3$ & 5 & $29,40 \pm 2,5$ & $31,40 \pm 3,1$ & $31,20 \pm 4,6$ & $29,00 \pm 4,5$ \\
\hline $\mathrm{p}$ & & $0,036^{*}$ & 0,086 & 0,236 & $0,009 *$ \\
\hline
\end{tabular}

Keterangan : $\mathrm{X}=$ rerata; $\mathrm{p}<0,05:$ Bermakna

Kadar NO $(\mu \mathrm{mol} / \mathrm{mL})$

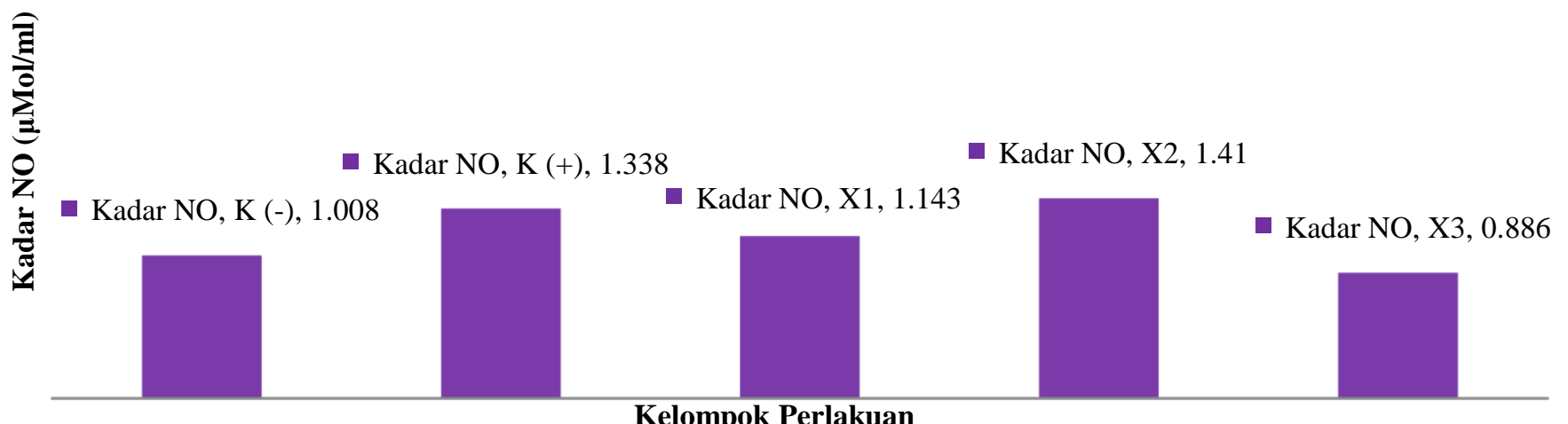

Kelompok Perlakuan

Gambar 1. Grafik kadar NO dalam serum darah

Keterangan : K (-) : Mencit swiss sehat; $\mathrm{K}(+)$ : Mencit swiss yang diinokulasi PbA; X1: Kelompok perlakuan yang diinokulasi $\mathrm{PbA}$ dan diberi ACT; X2 : Kelompok perlakuan yang diinokulasi PbA dan diberi tepung ulat sagu; X3 : Kelompok perlakuan yang diinokulasi $\mathrm{PbA}$, diberi tepung ulat sagu dan ACT.

Tabel 4. Uji Bonferroni Kadar NO Sirkulasi NO

\begin{tabular}{|c|c|c|c|c|c|c|}
\hline \multirow{2}{*}{ Kelompok Perlakuan } & \multirow{2}{*}{$\begin{array}{c}\text { Kadar NO }(\mu \mathrm{mol} / \mathrm{mL}) \\
\text { Mean } \pm \text { SD }\end{array}$} & \multicolumn{5}{|c|}{ Nilai p } \\
\hline & & $\mathbf{K}(-)$ & $\mathbf{K}(+)$ & $\mathrm{X} 1$ & $\mathrm{X} 2$ & X3 \\
\hline $\mathrm{K}(-)$ & $1,008 \pm 0,068$ & & 0,094 & 1,000 & $0,023^{*}$ & 1,000 \\
\hline $\mathrm{K}(+)$ & $1,338 \pm 0,162$ & & & 1,000 & 1,000 & $0,009^{*}$ \\
\hline $\mathrm{X} 1$ & $1,143 \pm 0,171$ & & & & 0,301 & 0,269 \\
\hline $\mathrm{X} 2$ & $1,410 \pm 0,174$ & & & & & $0,002 *$ \\
\hline X3 & $0,886 \pm 0,227$ & & & & & \\
\hline
\end{tabular}

Keterangan :

Nilai $p<0,05^{*} \quad$ : Bermakna

\section{Kadar Nitric Oxide (NO)}

Kadar NO sirkulasi diperoleh melalui pengukuran serum darah mencit Swiss yang diukur dengan reagen Griess dengan menggunakan microplate reader pada gelombang $595 \mathrm{~nm}$. Gambar 1 menunjukkan_kadar NO kelompok X3 paling rendah dibanding semua kelompok yang diteliti, sementara kadar NO kelompok X2 paling tinggi diantara kelompok yang diteliti. Kadar NO kelompok $\mathrm{K}(+)$ lebih tinggi dibanding kelompok K(-).

Uji normalitas kadar NO pada masing-masing kelompok menunjukkan bahwa data kadar NO berdistribusi normal pada semua kelompok $(p>0,05)$ dan homogen $(p>0,05)$. Berdasarkan hasil uji One Way
ANOVA dapat disimpulkan bahwa ada perbedaan yang signifikan antar kelima kelompok perlakuan $(p=0,001)$, kemudian dilakukan uji Bonferroni untuk mengetahui kelompok yang memiliki perbedaan bermakna (Tabel 4).

Tabel 4. menunjukan bahwa rerata kadar NO kelompok X2 lebih tinggi dari $\mathrm{K}(-)$ dan perbedaan ini bermakna dengan $(p=0,023)$, sementara kelompok X1 dan X3 tidak berbeda dari $\mathrm{K}(-)$. Temuan ini menunjukkan bahwa kadar NO dua kelompok perlakuan yaitu kelompok penerima ACT maupun kombinasi tepung ulat sagu dan ACT, mencapai kadar NO sehat. Rerata kadar NO kelompok dengan X1 lebih rendah dari $\mathrm{K}(+)$ walaupun demikian perbedaan 
bermakna sebanding $\mathrm{K}(+) \quad(p=0,009) \quad$ dan $\quad \mathrm{X} 2$ $(p=0,002)$. Temuan ini menunjukan bahwa perlakuan tepung ulat sagu pada penerima ACT,menurunkan kadar NO sirkulasi mencit Swiss hari ke \& pasca inokulasi $\mathrm{PbA}$.

\section{PEMBAHASAN}

Berdasarkan hasil menunjukkan rerata kadar NO pada $\mathrm{K}(+)$ lebih tinggi dari $\mathrm{K}(-)$ (Gambar 1). Kondisi infeksi yang menyebabkan inflamasi mengakibatkan peran ganda NO, yaitu sebagai mediator sentral pertahanan host dan agen penting dalam patogenesis kerusakan host. ${ }^{14} \mathrm{NO}$ merupakan suatu molekul berbentuk gas yang memiliki struktur relatif stabil dan sangat reaktif yang secara normal diproduksi oleh tubuh dalam jumlah yang kecil sebagai suatu zat fisiologis yang menunjang fungsi tubuh serta sebagai pelindung tubuh terhadap serangan agen pathogen yang memberikan sinyal kepada sel endotel dalam pembuluh darah. ${ }^{15}$ Kenaikan kadar NO kemungkinan diakibatkan terjadi infeksi dan inflamasi yang berlebihan dari $\mathrm{PbA}$. Penelitian ini selaras dengan penelitian Tjahjani 2016, menggunakan ekstrak etanol daun ungu (Gratophyllum pictum(L.)), bahwa infeksi yang berlebihan menyebabkan kenaikan jumlah NO yang lebih banyak dibanding kelompok K(-). Jumlah NO yang berlebihan akibat infeksi akan diubah menjadi peroksinitrit $\left(\mathrm{ONOO}^{-}\right)$yang merupakan radikal bebas sehingga sel mengalami stres oksidatif. ${ }^{10}$ Infeksi Malaria menginduksi pembentukan radikal hidroksil $(\mathrm{OH})$ di hati, yang kemungkinan besar merupakan alasan utama untuk induksi stres oksidatif dan apoptosis, serta eritrosit yang terinfeksi Plasmodium falciparum menghasilkan $\mathrm{OH}$ radikal dan $\mathrm{H} 2 \mathrm{O} 2$ sekitar dua kali lipat dibandingkan dengan eritrosit normal. Kontribusi NO sebagai radikal bebas dalam penghancuran Plasmodium, akan tetapi tingginya NO menyebabkan penekanan kekebalan dan mengarah pada perkembangan malaria serebral. ${ }^{15}$ Peningkatan rerata kadar NO pada kontrol positif kemungkinan terjadi hipoargininemia yang tentunya perlu diperkuat dengan pemeriksaan kadar plasma arginine, karena hipoargininemia terlihat pada hampir semua pasien dengan malaria berat. ${ }^{16}$

Peningkatan rerata kadar NO pada perlakuan X2 lebih tinggi dari $\mathrm{K}(-)$ dan perbedaan ini bermakna ( $p=0,023$; Tabel 4). Penelitian yang mengamati indeks parasit menunjukan bahwa rerata indeks parasit kelompok X2 adalah 14\%. Kandungan arginin tepung ulat sagu bersama dengan tingginya indeks parasit mendasari peningkatan kadar NO sirkulasi pada kelompok X2. Infeksi PbA memicu peningkatan kadar NO sirkulasi. ${ }^{17}$ Proses produksi NO diawali dari makrofag yang terpapar patogen sehingga jalur produksi reactive nitrogen intermediate (RNI) terinduksi. Tingginya kadar RNI akan merangsang iNOS dan terjadi sintesis NO 100-1000 kali lebih banyak. NO disintesis dari arginin di bawah kontrol enzimatik Nitrat Oksida Sintase (NOS). ${ }^{18}$ Sintesis NO membutuhkan asam amino L-Arginin. ${ }^{19}$ Peningkatan NO yang terlalu banyak akan mengakibatkan kerusakan oksidatif melalui hambatan respirasi sel sehingga menjadi salah satu penyebab terjadinya komplikasi pada penderita malaria. ${ }^{20}$ Kadar NO yang tinggi juga ditemukan pada penelitian Cramer, yang melibatkan anak usia kurang dari 24 bulan di Ghana dengan malaria berat termasuk diantaranya yang menderita anemi berat malaria dan malaria serebral dikaitkan dengan penurunan densitas parasitemi. Temuan tersebut walaupun demikian tidak teramati lagi pada usia anak lebih dari 24 bulan. Penelitian pada anak dengan malaria ini juga menunjukkan bahwa kadar NO tidak ada kaitan dengan terjadinya malaria serebral, mengingat penelitian sebelumnya memperlihatkan bahwa NO berperan mengganggu signal di otak yang mendasari terjadinya malaria serebral. ${ }^{21}$ Rendahnya kadar NO justru dikaitkan dengan kejadian eksperimental malaria serebral, dan perlakuan yang meningkatkan kadar NO justru memperpanjang survival, mencegah terjadainya eksperimental malaria serebral. ${ }^{22} \mathrm{NO}$ juga mempunyai efek protektif antara lain memperbaiki mikrosirkulasi otak sehingga melindungi mencit dari EMS. ${ }^{23}$ Keadaan yang mampu meningkatkan ketersediaan NO ternyata berdampak menguntungkan mencit EMS karena memperpanjang survival, menurunkan jumlah sel $\mathrm{T}$ CD4+ dan sel T CD8+ di otak, memperbaiki integritas blood-brain barrier (BBB). ${ }^{24}$ Berdasarkan hal tersebut, dalam penelitian ini perlu dilakukan uji survival pada mencit yang diinfeksi PbA.

Rendahnya ketersediaan NO di paru dan pembuluh darah pada malaria berat, ternyata berkorelasi dengan endogenous inhibitory NOS, an asymmetrical dimethylarginine (ADMA). ${ }^{25}$ Kadar NO serum anak dengan malaria lebih rendah secara bermakna dibanding anak sehat, bahkan anak dengan malaria berat mempunyai kadar NO serum yang lebih rendah dibanding anak dengan malaria tanpa komplikasi. ${ }^{11}$ Hal ini dimungkinkan mendasari rendahnya kadar NO pada malaria berat. Hipoargininemia ditemukan pada eksperimental malaria serebral dan anak dengan malaria serebral. Eksperimental malaria serebral menunjukan rendahnya ketersediaan arginine, ornithine, citrulline, dan rendahnya konversi dari citrulline menjadi arginine. ${ }^{26}$ Kandungan tepung ulat sagu kemungkinan mampu meningkatkan ketersediaan arginine, sehingga perlu dilakukan pengamatan plasma arginine untuk memperkuat temuan ini. Keuntungan suplemen nutrisi yang mengandung arginin selaras dengan penelitian air kelapa muda yang mengandung L-Arginin, terbukti 
menurunkan indeks parasit. ${ }^{27}$ Temuan ini tidak sejalan dengan temuan penelitian suplementasi L-arginin pada mencit eksperimental malaria serebral. Suplementasi $L$-arginin yang merupakan substrat NOS dalam pembentukan NO, berdampak menurunkan survival dan memperburuk skor malaria serebral dan meningkatkan populasi sel Th1 yang bersifat memperburuk malaria dengan komplikasi. ${ }^{28,29}$ Cara pengukuran yang berbeda mendasari perbedaan temuan penelitian pada penderita malaria dan penelitian suplementasi tepung ulat sagu. Pengamatan ketersediaan NO pembuluh darah dan dampaknya pada vasospasme dengan pengamatan peripheral arterial tonometry telah dikaji Eisenhut. ${ }^{30}$ Pengukuran dengan peripheral arterial tonometry pada penelitian suplementasi tepung ulat sagu akan memperjelas bahwa kadar NO sirkulasi masih cukup berdampak baik pada tonus pembuluh darah.

Kadar NO pada kelompok X1 lebih rendah dari kelompok $\mathrm{K}(+)$, walaupun demikian berbeda pada kedua kelompok X3 dibanding $\mathrm{K}(+)(p=0,009)$. Rerata kelompok X1 dan X3 tidak berbeda dari kelompok K(). Hal ini menunjukan bahwa kadar NO penerima ACT maupun kombinasi tepung ulat sagu dan ACT mencapai kadar NO sirkulasi kelompok sehat. Ketersediaan NO pada kelompok X1 dan X3tersebut kemungkinan sudah tidak diperlukan karena memasuki fase penyembuhan. NO menghambat ekspresi gen lain yang terlibat dalam patogenesis eksperimental serebral malaria serta menghambat inflamasi neuroin yang terkait dengan infeksi plasmodium melalui mekanisme yang melibatkan induksi heme oxygenase-1 (HO-1). ${ }^{29}$ Artemisinin telah terbukti sangat efisien dalam pengobatan malaria berat karena dapat menghambat pelepasan TNF- $\alpha$ dan NO serta menghambat metabolisme parasit dan menurunkan indeks parasit. ${ }^{31}$ Hal ini sejalan dengan temuan penelitian paralel yang mengamati parasitemia yang memperlihatkan bahwa indeks parasitemia pada kelompok X1 0,5\% dan pada perlakuan X3 sebanyak 0,3\%. Perlakuan X3 menunjukan bahwa berbeda bermakna dengan kelompok K(+). Pemberian kombinasi tepung ulat sagu dan DHP ACT pada kelompok X3 menunjukan dampak penurunan bermakna kadar NO dibanding $\mathrm{K}(+)$ (Tabel 4). Antioksidan dalam tepung ulat sagu mampu menghambat stres oksidatif yang terjadi akibat infeksi. Adanya interaksi penggunaan artemisinin dengan tepung ulat sagu yang memiliki kandungan protein yang memicu imunitas melawan parasit malaria pada fase aseksual, dan mempunyai transmisionblocking activity yang digunakan dalam menghambat transmisi siklus malaria. ${ }^{16}$ Penggunaan antioksidan sebagai terapi suportif yang dikombinasikan dengan ACT dianggap penting untuk mempercepat proses kesembuhan serta mengurangi kerusakan jaringan normal yang lebih berat akibat pembentukan radikal bebas yang berlebihan. DHP merupakan metabolit aktif dari artemisinin yang lebih efektif mengeliminasi parasit dalam tubuh, meningkatkan kadar hemoglobin. ${ }^{32}$

\section{SIMPULAN}

Efek imunomodulator tepung ulat sagu (Rhyinchophorus ferrugineus) berasosiasi dengan penurunan kadar NO sirkulasi pada mencit yang diterapi antimalaria standar. Disarankan uji perbedaan dosis ulat sagu dan kombinasi ACT terhadap kadar NO pada mencit dengan infeksi $\mathrm{PbA}$, serta penggunaan strain mencit C57BL untuk memperjelas efek protektif dari ulat sagu.

\section{UCAPAN TERIMA KASIH}

Ucapan terima kasih kepada Dinas Kesehatan Kabupaten Teluk Bintuni Propinsi Papua Barat atas obat antimalaria DHP-FRIMAL produksi PT. Mersi farma TM.

\section{DAFTAR PUSTAKA}

1. World Health Organization. Media centre malaria. 2017. Available from: http://www.who.int/mediacentre/factsheets/fs094 len.

2. Pusat Data dan Informasi Kementerian Kesehatan RI. Info Datin Malaria. Malaria; 2016.1-7.

3. Kementrian Kesehatan RI. Pedoman tatalaksana malaria. Peraturan Menteri Kesehatan RI; 2013.162.

4. Sucipto CD. Manual lengkap malaria. Yogyakarta: Gosyen Publishing; 2015.125-129.

5. Zulkoni A. Parasitologi. Nuha Medika; Yogyakarta; 2011.79-87.

6. Estela M, Prameshinta F, Dharmana E, Kisdjamiatun RA. Efektivitas ekstrak daun sirsak (annonamuricata) dalam menurunkan kadar TNF$\alpha$ dan meningkatkan kadar NO uji coba pada mencit swiss yang diinokulasi plasmodium berghei ANKA. J Kedokteran Brawijaya. 2016;29(1):39-42.

7. Upadhyay DN, Vyas RK, Sharma ML, Soni Y, Rajnee. Comparison in serum profile of peroxidants (MDA) and non enzymaticanti oxidants (vitamins $\mathrm{E}$ and $\mathrm{C}$ ) among patients suffering from plasmodium falciparum and vivax malaria. J Postgrad Med Inst. 2011;25(2):96-100.

8. Cabrales P,Zanini GM, Barkho W, Frangos JA, Carvalho LJ. Exogenous nitric oxide decreases brain vascular inflammation, leakage and venular resistance during Plasmodium berghei ANKA 
infection in mice. $\mathrm{J}$ Neuroinflammation. 2011;8(1):66.

9. Punsawad C. Effect of malaria components on blood mononuclear cells involved in immune response. Asian Pacific Journal of Tropical Biomedicine. 2013;3(9);751-756.

10. Tjahjani NP, Kristina TR, Lestari ES. Efektivitas ekstra ketanol daun ungu (Gratophyllumpictum (L.) untuk menurunkan kadar TNF- $\alpha$ dan NO. Pharmaciana. 2016;6(2):191-200.

11. Osaro E, Muhammad K, Yakubu A, Zama I, Jiya NM, Van Dyke K, Nonye E: Serum nitric oxide levels among pre- school children of african descent with malaria in Sokoto, Nigeria. EC Paediatrics. 2017;5(4):97-107.

12. Bustaman S. Potensi ulat sagu dan prospek pemanfaatannya. J Litbang Pertanian. 2008;27(7):50-54.

13. Hastuty S. Pengolahan ulat sagu (Rhynchophorus ferrugineus) di Kelurahan Bosso Kecamatan Walenrang Utara Kabupaten Luwu. J Perspektif. 2016;01(1):12-9.

14. Tafor D. Pengaruh pemberian ekstrak etanol buah merah (Pandanusconoideus Lam) terhadap kadar Tumor Necrosis Factor Alpha (TNF- $\alpha$ ) dan ekspresi Intercellular Adhesion Molecule-1 (ICAM-1) mencit swiss (Musmusculus L) yang diinfeksi Plasmodium berghei [Tesis]. Universitas Gadjah Mada; 2014.

15. Percario S, Moreira DR, Gomes BAQ, Ferreira MES, Goncalves ACM, Laurindo PSOCL, Vilhena TC, Dolabela MF. Green MD. Oxidative stress in malaria. International Journal of Molecular Sciences. 2012;13:16346-16372

16. Weinberg JB, Lopansri BK, Mwaikambo E, Granger DL: Arginine, nitric oxide, carbon monoxide, and endothelial function in severe malaria. Current opinion in infectious diseases. 2008; $21: 468-75$.

17. Gomes BAQ, Silva LFD, Gomes ARQ, Moreira DR, Dolabela MF, Santos RS, Green MD, Carvalho EP, Percario S. N-acety cysteine and mushroom Agaricus sylvaticus supplementation decreased parasitemia and pulmonary oxidative stress in a mice model of malaria. 2015;14:202.

18. Hawkes M, Opoka RO, Namasopo S, Miller C, Thorpe KE, Lavery J V, et al. Inhaled nitric oxide for the adjunctive therapy of severe malaria: Protocol for a randomized controlled trial. J Trials. 2011;12(1):176.

19. Nahrevanian H. Immune effector mechanisms of the nitric oxide pathway in malaria: cytotoxicity versus cytoprotection. The Brazilian Journal of Infectious Diseases. 2006;10(4):283-292.
20. Sayuti K, Yenrina R. Antioksidan alami dan sintetik. Andalas University Press. Padang. 2015:1-5.

21. Fitri LE, Sarwono I, Rahmalia R. Kombinasi klorokuin dan $N$-Acetyl cysteine menurunkan ekspresi $i N O S$ Tubulus proksimal ginjal mencit yang diinfeksi Plasmodium berghei. Jurnal Kedokteran Brawijaya. 2011;26(4):221-226.

22. Cramer JP, Nussler AK, Ehrhardt S, Burkhardt J, Otchwemah RN, Zanger P, Dietz E, Gellert S, Bienzle U, Mockenhaupt FP: Age-dependent effect of plasma nitric oxide on parasite density in Ghanaian children with severe malaria. Tropical medicine \& international health : TM \& IH. 2005;10:672-680.

23. Gramaglia I, Sobolewski P, Meays D, Contreras R, Nolan JP, Frangos JA, Intaglietta M, van der Heyde HC: Low nitric oxide bioavailability contributes to the genesis of experimental cerebral malaria. Nature medicine. 2006;12:1417-1422.

24. Cabrales P, Zanini GM, Meays D, Frangos JA, Carvalho LJM. Nitric oxide protection against murine cerebral malaria is associated with improved cerebral microcirculatory physiology. J Infection Disease. 2011;203(10):1454-1463.

25. Elphinstone RE, Besla R, Shikatani EA, Lu Z, Hausladen A, Davies M, Robbins CS, Husain M, Stamler JS, Kain KC. S-Nitrosoglutathione reductase deficiency confers improved survival and neurological outcome in experimental cerebral malaria. Infection and immunity. 2017;85(9):1-39.

26. Yeo TW, Lampah DA, Tjitra E, Gitawati R, Darcy CJ, Jones C, Kenangalem E, McNeil YR, Granger DL, Lopansri BK, Weinberg JB, Price RN, Duffull SB, Celermajer DS, Anstey NM. Increased asymmetric dimethylarginine in severe falciparum malaria: association with impaired nitric oxide bioavailability and fatal outcome. PLoS pathogens. 2010;6(4):1-8.

27. Alkaitis MS, Wang H, Ikeda AK, Rowley CA, MacCormick IJ, Chertow JH, Billker O, Suffredini AF, Roberts DJ, Taylor TE, Seydel KB, Ackerman HC. Decreased rate of plasma arginine appearance in murine malaria may explain hypoargininemia in children with cerebral malaria. The Journal of infectious diseases. 2016;214:1840-1849.

28. Mulyanti, Dharmana E, Djamiatun K, Wijayahadi $\mathrm{N}$. Effectiveness of tender coconut water (cocosnucifera 1) against parasitemia index and hemoglobin levels in malaria infection. International Journal of Pharmaceutical Sciences and Research. 2016;7(9):3873-3876. 
29. Eisenhut M. The evidence for a role of vasospasm in the pathogenesis of cerebral malaria. Malaria Journal. 2015;14:405

30. Xu H, Feng Y, Chen G, Zhu X, Pang W, Du Y, Wang Q, Qi Z, Cao Y: L-arginine exacerbates experimental cerebral malaria by enhancing proinflammatory responses. The Tohoku journal of experimental medicine. 2015;236:21-31.
31. Jeney V, Ramos R, bergman ML, Bechmann I, Tischer J, Ferreira A, Marques VO, Janese CJ, Rebelo S, Cardoso S, Soares MP. Control of disease tolerance to malaria by Nitric Oxide and Carbon Monoxide. Cell Reports. 2014:8(1);126136.

32. Shakir L, Hussain M, Javeed A, Ashraf M, Riaz A. Artemisinins and immune system. European Journal of Pharmacology. 2011;668:6-14. 